\title{
Self-Management of Rheumatic Diseases- State of the Art and \\ Future Perspectives
}

\begin{abstract}
Maura D Iversen ${ }^{1,2}$, Alison Hammond ${ }^{3}$, Neil Betteridge ${ }^{4}$
${ }^{1}$ Department of Physical Therapy, Bouve College of Health Sciences, Northeastern University,

${ }^{2}$ Section of Clinical Sciences, Division of Rheumatology, Immunology \& Allergy, Brigham \&

Women's Hospital, Harvard Medical School, Boston, MA USA ${ }^{3}$ Centre for Health, Sport \&

Rehabilitation Research, University of Salford, Salford, UK ${ }^{4}$ Arthritis Care, London, UK
\end{abstract}

\section{Corresponding Author:}

Maura Daly Iversen, PT, DPT, SD, MPH

Professor and Chair, Department of Physical Therapy

Bouve College of Health Sciences

Northeastern University

301 C Robinson Hall

360 Huntington Avenue

Boston, MA 02115

Tel (617) 373-5996 fax (617) 373-3161

Email:m.iversen@neu.edu

Keywords: Self-management, arthritis, patient perspectives 


\section{ABSTRACT}

Self-management interventions (SMIs) are patient-centered and designed to foster active participation of patients in order to promote well-being and to manage symptoms. Over the past two decades the role of self-management in chronic diseases has gained momentum. Selfmanagement programs are now acknowledged as a key element of quality care. New modes of delivery allow greater access to information and are tailored to address patient needs. This systematic review presents data from clinical studies of self-management over the past decade, summarizes the evidence for program effectiveness and suggests future research directions. 


\section{INTRODUCTION}

Self-management is the "individual's ability to manage the symptoms, treatment, physical and psychosocial consequences and life style changes inherent in living with a chronic condition" ${ }^{1}$. Whilst often instigated by individuals, health professionals, and patient organizations facilitate self-management in partnership with patients. Traditional patient education offers information and technical skills. In contrast, self-management interventions (SMls) are problem focused, actionoriented and emphasize patient-generated care plans ${ }^{2}$. SMIs include educational, behavioural and cognitive approaches to influence health knowledge, attitudes, beliefs and behaviours and to promote independence, maintain or adjust life roles and address the psychological impact of disease. SMls address five skills: problem solving, decision-making, resource utilization, collaborative patient/provider relationships and taking action ${ }^{3}$. SMI success depends upon needs assessments identifying specific groups' concerns.

\section{Importance and meaning of self-management for persons with arthritis}

Health professionals view SMIs as structured education to develop patients' illness management skills. However, patients view these differently ${ }^{4}$. A qualitative study ${ }^{5}$ reported arthritis patients viewed SMls as a way to bring order into their lives, helping them recognize boundaries, mobilize resources, cope with change in self-identity and plan, pace and prioritize. This study furthers the understanding of SMIs because it identifies and articulates the value of patient-centered approaches and has implications for SMI evaluation in terms of frequency and methodology. SMI evaluation occurs in stages; pre-, intra- and post-intervention, representing a series of snapshots along a continuum and may miss the full impact on the patient. Additionally, differences in outcome data may occur based on who has asked questions and how questions were asked.

\section{History of self-management programs}

In the 1980s, Lorig and associates developed the Arthritis Self-Management Program (ASMP) to enhance well-being and quality of life. The original ASMP was not theory based but considered knowledge leads to behaviour change. During program evaluation participants linked 
program satisfaction with an increased sense of disease control ${ }^{6}$ thus Bandura's Social Cognitive Theory ${ }^{7}$ was selected as a framework for change. As more SMls developed, researchers recognized the value of peer- as well as professional- led programs ${ }^{8}$. Lorig's ASMP is the most developed and studied of SMIs and is disseminated by patient organizations across the globe.

Most SMI research evaluates group programs delivered face-to-face. Financial constraints, increasing access and technology have driven mailed and internet program development. The ASMP group (Stanford University, USA) leads the way developing new technologies for selfmanagement. However, many SMIs are still delivered one-to-one by health professionals, the least evaluated delivery mode.

\section{EVIDENCE FOR EFFECTIVENESS OF SELF-MANAGEMENT PROGRAMS}

Several systematic reviews of arthritis patient education and SMIs have evaluated studies published up to 2002. Reviews of rheumatoid arthritis (RA) SMls concluded only those using psychobehavioural approaches led to short-term (up to 9 months) significant improvements in functional disability, but effects are not sustained ${ }^{9,10}$. Osteoarthritis $(O A)$ and RA study reviews concluded $40 \%$ of SMls led to improved symptoms and disability ${ }^{11,12}$. Effective programs were more common in OA than RA, possibly because OA SMIs more frequently included exercises and recruited larger samples. Programs based on cognitive-behavioural theory (CBT) or social cognitive theory (SCT) yielded better outcomes. Few studies examined effectiveness for 12 months or more. Two systematic reviews of SMI trials in FM concluded that multimodal interventions yielded better outcomes than single mode interventions but improvements were modest and not maintained ${ }^{13,14}$.

Methodological limitations of SMI trials were highlighted such as: insufficient patient-relevant outcomes, lack of consensus for outcomes and patient attributes examined; and low statistical power. Recommendations for future SMI trials included: use of OMERACT core sets; assessment of fatigue and social participation; sufficient power; be disease specific; identify which patient and program characteristics yield beneficial outcomes; explicitly state theoretical basis; publish program protocols /manuals; use leaders trained in group facilitation, problem- 
solving, goal-setting and CBT and/or SCT approaches; and use strategies for long-term behavioural change (eg booster sessions) ${ }^{10,12}$.

For this review, Medline, PubMed, EMBASE, CINAHL, AMED, PsychInfo and the Cochrane Library were searched from 2000 for FM, from 2003 for OA and RA and up to November 2009 using key terms of "arthritis," "osteoarthritis, " "rheum\$," "fibromyalgia," "self-management," self care " and "patient education." Studies were included if they: were in English; involved randomization; and stated they were SMIs. In total, 30 articles were identified meeting the entry criteria; some were economic evaluations and long-term follow-ups of earlier trials. Studies were excluded if only reporting observational data or long-term follow-up data from previous trials without comparison group data. This review aims to identify whether longer-term (ie $>=12$ months) benefits resulted, by diagnosis and if any program or patient characteristics are associated with improvement.

\section{SMIs for individuals with either OA, RA or other arthritic conditions.}

Seven studies were identified: two being published within one article and three articles related to one study ${ }^{15-22}$. See Table 1. Fifty to $75 \%$ of participants had OA, 15 to $35 \%$ RA and 15 to $17 \%$ other diagnoses. Two studies included between $30-52 \%$ of people with FM (who could have other arthritis diagnoses) ${ }^{17,21}$. Six studies evaluated the ASMP or variations thereof, all including weekly exercise practice (stretch, strength and walking). Two evaluated the ASMP ${ }^{16,21}$; two a mailed, individualized version of the ASMP (SMART: provided over $12-18$ months) ${ }^{15}$; one an internet- ASMP ${ }^{17}$; and one a "one-time" mailed ASMP version ${ }^{22}$. The seventh evaluated the individually tailored "I'm Taking Charge of My Arthritis" (ITCA) program provided in individual

home visits ${ }^{18-20}$. All were community or home-based and all (apart from the ITCA study led by health professionals) led by either peer moderators or self-completed. All programs involving contact lasted 6 weeks (in person or internet) and the other two self-completed at a pace to suit participants. Two studies included booster sessions ${ }^{15,18,19}$. Apart from the ITCA, all programs included similar ASMP content and teaching strategies. Cognitive and behavioural strategies were taught by trained leaders, following the ASMP leader manual, using SCT approaches to 
facilitate change.

Methodologically, five studies used intent-to-treat (ITT) analysis ${ }^{15,16,22}$ (and only four included control groups ${ }^{15,17,18,22}$.Two conducted a priori sample size analyses and recruited sufficient participants ${ }^{21,22}$ and a further four ${ }^{15-17}$ recruited between 340-1090 patients suggesting these were large enough to detect differences.

All studies evaluated pain, function, mood, self-efficacy, and health behaviors. (Table 5). Five reported follow-ups of 12 months or longer ${ }^{15-17,21}$. At 12 months, all five demonstrated improvements in self-efficacy; four in function (Lorig et al 2004, 2005, 2008); two in pain ${ }^{15}$, ${ }^{18}$; and one in mood ${ }^{18}$. The least effective ASMP recruited predominantly African American participants 21. Most effective ASMP studies were delivered to predominantly non-Hispanic white participants, either face to face ${ }^{15}$ or via the Internet ${ }^{17}$. Most participants (64-75\%) had OA. Only one study conducted sub-group analyses by diagnoses, demonstrating the Internet ASMP was most effective in $\mathrm{OA}$, next in RA and not at all in $\mathrm{FM}^{17}$. Follow-up longer than 12 months occurred in only one study with a control group comparison. At two years, the SMART programme, including booster materials, reduced perceived arthritis severity and doctor visits but by three years, there were no differences ${ }^{15}$.

\section{SMls for individuals with osteoarthritis}

Eight studies were identified ${ }^{23-30}$. Economic analyses were conducted for two studies ${ }^{31,32}$. See Table 2. Three studies enrolled only patients with knee OA and five patients with hip and/or knee OA. Three used a cluster RCT approach with medical practices as the unit of analysis ${ }^{23,24,28}$. Most participants, approximately $75 \%$, were women. Three studies evaluated the groupformat ASMP ${ }^{25,29,30}$. Five evaluated other SMls, comparing these to usual care or information booklets ${ }^{23,24,26-28}$. Three studies were group interventions: two combining SMls with supervised and home exercise practice ${ }^{24,27}$; and two evaluated individual SMIs ${ }^{26,28}$. Most group interventions lasted 12 hours over 6 weeks, apart from one of four hours plus an individual home visit $^{23}$. None included booster sessions. Individual interventions lasted one hour ${ }^{26}$ or duration was not stated ${ }^{28}$, with both including telephone follow-up. All but one study ${ }^{29}$ recruited patients from primary care. All but one ${ }^{25}$ were led by a health professional, either GP, nurse and/or physical 
therapist, and group SMIs used SCT approaches. Methodologically, five studies used ITT analysis ${ }^{25,27-30}$ and a priori power calculations were reported in four. (See Table 2)

All studies evaluated pain and function; four also examined health knowledge, behaviors and care use; three measured self-efficacy; but mood and fatigue were infrequently assessed (See Table 5). Four studies only reported short-term outcomes (between 4 to 9 months): with three reporting improvements in pain and function ${ }^{27-29}$; and one brief individual SMI reporting no differences ${ }^{26}$. Two studies found no significant differences in outcomes at any follow-up, both having shorter duration interventions of one or five hours ${ }^{23,26}$. Two studies ${ }^{24,25}$ included economic analyses. Whilst both had health benefits only one demonstrated cost-effectiveness ${ }^{32}$ : a group format being better than individual interventions ${ }^{27}$. Overall, of the four studies evaluating long-term outcomes (ie 12 months or longer) significant, modest effects were found for: pain ${ }^{24,30}$; self-efficacy ${ }^{25,30}$; function ${ }^{24}$ and mood $^{25}$. The most effective interventions longer-term were protocolized group SMls, including six weeks of supervised exercise, using either CBT or SCT approaches led by trained leaders ${ }^{24,30}$.

\section{SMls for individuals diagnosed with inflammatory arthritis}

Five studies were identified ${ }^{33-37}$ (Table 3). Four recruited people with RA only and one, pragmatically, RA (50\%), early inflammatory arthritis (35\%) and psoriatic arthritis (14\%) ${ }^{37}$. Three studies recruited people with well-established disease (average 12-15 years) and two early to established disease ${ }^{34,37}$. Studies showed some similarities: all evaluated small group programs (up to 10 participants), were hospital-based and led by health professionals. All except one ${ }^{34}$ had control groups, either usual care, information booklets or attention control (an information program). All used ITT analysis. In other respects studies were diverse. Sample sizes ranged from 59 to 218 , with only three reporting sample size analyses and recruiting sufficient participants to detect differences ${ }^{33,36,37}$.

Programme duration varied from 12 -52 hours, over 6 weeks to 9 months, with three including booster sessions (between 3 to 9 months post-programme). Programs also varied in content and delivery. All provided information about the disease and medications. Four explicitly used SCT 
and/or CBT approaches. Two were led by clinical psychologists using CBT combined with education from multidisciplinary team members using "more traditional didactic approaches" for physical strategies ${ }^{34,35}$. Two described use of leader manuals, staff training in SCT/CBT approaches and applying these throughout programs ${ }^{33,37}$. One study did not explicitly describe its theoretical framework ${ }^{36}$. Only two included regular exercise ${ }^{36,37}$.

All studies evaluated pain, function and mood. Disease status and self-efficacy were measured in four and fatigue in three studies (Table 5). Short-term benefits were found in four studies. Three had longer-term follow-up at 12 months but only two showed benefits ${ }^{33,37}$. Both used SCT/CBT approaches throughout the programs, specially trained health professionals and longer-term booster sessions. Riemsma et al ${ }^{33}$ identified improved self-efficacy and fatigue in people attending a primarily cognitive strategy SMP without their partner, whilst those attending with partners showed no sustained benefits. Hammond et al ${ }^{37}$ (2008) showed significant improvements in pain, self-efficacy, perceived control and health behaviours. This was the only program consistently enabling both cognitive and behavioural strategies using SCT/CBT approaches with substantial skills practice. Patients also had shorter disease duration (average 7 compared to $12-15$ years).

\section{SMIs for individuals diagnosed with fibromyalgia}

Seven studies were identified ${ }^{38-44}$ (Table 4). Five recruited people from secondary care diagnosed with FM by rheumatologists using ACR criteria and two recruited patients from primary care diagnosed by General Practitioner ${ }^{38,42}$. Programs were similar with respect to group size (up to 12 participants) and leadership (health professionals). Additionally, an eighth study

(Internet- ASMP) reported FM results separately ${ }^{17}$ (Table 1). Most studies included a control group of usual care, wait list control, information leaflets or an attention control (relaxation) group. Only one had no control group, comparing exercise, SMI or combined exercise and SMI ${ }^{44}$. Sample sizes ranged from 53 to 207 , with all but two ${ }^{38,40}$ including sample size calculations and recruiting sufficient numbers to potentially demonstrate differences. Only four included ITT analysis ${ }^{17,39,42,43}$. Program duration varied between $18-50$ hours, with four being wholly or 
partially community based (e.g. leisure centres, YMCAs). Four programs lasted between 2.5 to 6 weeks and four between 10-16 weeks. None included booster sessions.

All programs included information about FM and its management. Nine different SMls were evaluated, as one study evaluated two styles of $\mathrm{SMI}^{38}$. Of these, six explicitly used SCT and/or CBT approaches with four reporting use of trained leaders experienced in these (CBT group only $\left.{ }^{38}\right) ;{ }^{17,43,44}$. All included cognitive components (e.g. managing pain, relaxation) and six included supervised exercise practice. A systematic review identified supervised moderate intensity aerobic exercise (minimum 12 weeks, 3x/week) is effective in $\mathrm{FM}^{45}$. However, only two programs combined SMls with this exercise intensity ${ }^{39,44}$, with only one showing short-term improvements ${ }^{44}$. Three studies included at least 10 sessions of supervised exercise spread over $6-10$ weeks $^{40,42,43}$.

All studies evaluated pain, function, perceived health and mood. Fatigue was measured in seven, self-efficacy and social role/support in four, health behaviours in three and health care use in only two (see Table 5). Considering studies using either case-completer or ITT analysis, shortterm benefits were found for 4-6 months in three studies for three or more outcomes ${ }^{40,43,44}$. Three had controlled follow-ups between 8-12 months ${ }^{17,41,43}$ but only two showed minimal continued benefits: in fitness ${ }^{41}$ and self-reported improvement ${ }^{43}$. In summary, no FM studies showed SMIs, with or without exercise, sustained benefits across a range of outcomes for more than 6 months.

\section{SUMMARY OF THE EVIDENCE}

Previous reviews have identified psychobehavioural SMls lead to short-term benefits (ie 6-9 months) but that longer-term benefits are infrequently evaluated and rarely sustained ${ }^{12,33}$. In this updated review we aimed to identify whether recent SMI trials identify any longer-term benefits and whether any program, diagnostic or patient characteristics are associated with improved outcomes.

Of the 30 studies identified, only 14 had follow-ups of 12 months or longer, seven of which (two of the same SMART ASMP) led to sustained benefits in pain and/ or function. All were methodologically sound. Little is known about benefits beyond 12 months as only two had longer-term follow-ups, although both demonstrated some continuing benefits ${ }^{15,24}$. The ASMP 
leads to sustained benefits over four years and is cost-effective ${ }^{46}$, but more research is needed in other SMIs. We recommend SMI studies demonstrating benefits at 6-12 months seek funding to extend follow-up and evaluate cost-effectiveness, to provide data for service development decisions.

In terms of program characteristics, the seven effective SMls were either the group ASMP, a variant (SMART or internet versions) ${ }^{15-17,30}$ or acknowledged ASMP influence on structure and format ${ }^{24,37}$. Thus, common program features were: duration of at least six weeks; explicit use of SCT and/or CBT approaches; individualized weekly action plans with progress review; highly protocolized with participant handbooks; and led by the same trained leaders. All face-to-face programs included weekly supervised exercise and graded home aerobic exercise (eg walking, Tai Chi). Three included aerobic exercise within programs ${ }^{25,30,37}$ and the mailed/ internet ASMPs strongly promoted exercise action-planning with clear details about exercise performance. We recommend these strategies be incorporated into clinical programs and in research trials. Evidence-based guidelines should include studies meeting SMI criteria ${ }^{3}$ and not treat all interventions equally. Whilst eight studies used boosters ${ }^{15,18,19,20,28,33,35-37}$ only three showed significant benefits ${ }^{15,28,37}$. Further evaluation of the timing, delivery (phone, mailing or group) and effectiveness of booster sessions is warranted.

In terms of patient characteristics, there is little research regarding who benefits most from SMls. The majority of ASMP trials recruited community or online volunteers, who may be more motivated to change. In ASMP studies recruiting from primary or hospital settings (all with OA) there is conflicting evidence, as two studies (with enhanced exercise) were effective ${ }^{29,30}$ but a third, was not ${ }^{25}$, supporting an earlier study's findings ${ }^{47}$. Only one ASMP trial has evaluated whether different diagnostic groups fare better, concluding the internet version is more effective in $\mathrm{OA}$, less so in RA and not in FM ${ }^{17}$. Another study ${ }^{33}$ reported patients with RA attending without their partner fared better, as they could openly discuss problems without loved ones present. Additionally, those not benefitting seemed less motivated to participate and change, had poorer heath and more stressful life events ${ }^{4}$. In an FM study, patients with initially higher self-efficacy 
reported greater improvements ${ }^{43}$. Further research is needed to appropriately target interventions and/or modify SMls to meet the needs of specific patient groups.

\section{FUTURE DIRECTIONS}

To best address the needs of patients with arthritis, we recommend researchers demonstrating positive outcomes from SMls with sufficient sample sizes, undertake secondary analyses to investigate whether any baseline characteristics may predict better outcomes. We also recommend evaluating longer-term (12 months or more) benefits of SMIs, using protocolised SCT/CBT based programs of sufficient duration, incorporating exercise for 6 sessions or more, (longer for FM, including twice-weekly supervised graded aerobic exercise), led by either specially trained health professionals or peer leaders and which incorporate assessment of patient-relevant outcome. Increased use of qualitative methods integrated into clinical trials (eg patient dairies (written or audiorecorded), focus groups or interviews) are suggested to promote participants' expression of any perceived benefits on overall well-being, and to explore their perspectives on SMI effectiveness, as opposed to the sole use of questionnaires using standard validated tools which may not be detecting meaningful differences to the patients. For example, a woman attending a SMI course reported walking to her local shops for the first time in 12 years. Taking over two hours to make the 200 yard trip was entirely irrelevant to her. Such change is not captured in outcome measures. Her ability to control to her life was her relevant outcome. Use of such qualitative approaches will help investigate the full impact of SMIs on individuals, determine the most patient-relevant outcomes for future trials, investigate the process of change and shed light on what patient attributes influence benefits (or lack of) to better target and time SMls. See

\section{Table 6.}




\section{REFERENCES}

1. Barlow J, Wright C, Sheasby J et al. Self-management approaches for people with chronic conditions: a review. Patient Education and Counseling 2002;48:177-187.

2. Lorig KR, Holman HR. Self-management education: History, Definition, Outcomes, and Mechanisms. Ann Behav Med 2003;26: 1-7.

3. Center for the Advancement of Health: Essential elements of self-management interventions. Washington, DC: Center for the Advancement of Health, 2002.

4. Bode C, Taal E, Emons PA, Galetzka M, Rasker JJ, van de Laar. Limited results of group self-management education for rheumatoid arthritis patients and their partners: Explanations from the patient perspective. Clin Rheumatol 2008;27:1523-1528.

5. Kralik D, Koch T, Price K, Howard N. Chronic illness self-management: Taking action to create order. J Clinical Nurs 2004:13:259-267.

6. Lorig KR, Seleznick M, Lubeck D et al. The beneficial outcomes of the arthritis selfmanagement course are not adequately explained by behavior change. Arthritis Rheum 1989;32: 231-243.

7. Bandura A. Self-efficacy: Toward a unifying theory of behavior change. Psychol Rev $1977 ; 84: 191-215$.

8. Lorig K, Feigenbaum P, Regan C, Ung E, Chastain RL, Holman HR. Comparison of laytaught and professional-taught arthritis self-management courses. J Rheumatol 1986;13:763767.

9. Niedermann K, Fransen J, Knols R, Uebelhart D. Gap between short-and long-term effects of patient education in rheumatoid arthritis patients: a systematic review. Arthritis Rheum 2004;51:388-398.

10. Riemsma R, Taal E, Kriwan J, Rasker JJ. Systematic review of rheumatoid arthritis patient education. Arthritis Rheum 2004;51:1045-1059.

11. Warsi A, LaValley MP, Wang PS, Avorn J, Solomon DH. Arthritis self-Management Programs: a meta-analysis of the effect on pain and disability. Arthritis Rheum 2003;48:2207- 
2213.

12. Newman S, Steed L, Mulligan K. Self-management interventions for chronic illness. The Lancet 2004;364:1523-1537.

13. Karjalainen KA, Malmivaara A, van Tulder MW, Roine $R$, Jauhiainen $M$, Hurri $H$, Koes BW. Multidisciplinary rehabilitation for fibromyalgia and musculoskeletal pain in working age adults. Cochrane Database of Systematic Reviews 1999, Issue 3. Art. No.: CD001984. DOI: 10.1002/14651858.CD001984.

14. Sim J, Adams N. Systematic review of randomised controlled trials of nonpharmacological interventions for fibromyalgia. Clinical J Pain 2002;18:324-336.

15. Lorig KR, Ritter PL, Laurent DD, Fries JF. Long-term randomized controlled trials of tailoredprint and small-group arthritis self-management interventions. Medical Care 2004;42:346-354. 16. Lorig K, Ritter PL, Plant K. A disease specific self-help program compared with a generalized self-help program for arthritis patients. Arthritis \& Rheumatism 2005;53:950-957. 17. Lorig K, Ritter P, Laurent DD, Plant, K. The Internet-based arthritis self-management program: A one-year randomized trial for patients with arthritis or fibromyalgia. Arthritis Rheum 2008;58:1009-1017.

18. Nour K, Laforest S, Gauvin L, Gignac M. Behavior change following a self-management intervention for housebound older adults with arthritis: An experimental study. Int J Behavioral Nutrition and Physical Activity 2006;3:12 (doi:10.1186/1479-5868-3-12).

19. Nour K, Laforest S, Gauvin L, Gignac M. Long-term maintenance of increased exercise involvement following a self-management intervention for housebound older adults with arthritis. Int J Behav Nutr Phys Act. 2007; 4:22. doi: 10.1186/1479-5868-4-22.

20. Laforest S, Nour K, Gignac M, et al. Short-term effects of a self-management intervention on health status of older housebound adults with arthritis. Journal of Applied Gerontology 2008;27:539-567

21. Goeppinger J, Armstrong B, Schwartz T, Ensley D, Brady TJ. Self-management education for persons with arthritis: Managing comorbidity and eliminating health disparities. Arthritis Rheum[Arthritis Care Res] 2007;57:1081-1088. 
22. Goeppinger J, Lorig K, Ritter PL, Mutatkar S, Villa F, Gizlice Z. Mail-delivered arthritis selfmanagement tool kit: a randomized controlled trial and longitudinal follow-up. Arthritis \& Rheumatism 2009;61:867-875.

23. Victor CR, Triggs E, Ross F, Lord J, Axford JS. Lack of benefit of a primary care based nurse-led education programme for people with osteoarthritis of the knee. Clinical Rheumatology 2005;24:358-364.

24. Heuts PH, de Bie R, Drietelaar M, Aretz K, Hopman-Rock M, Bastiaenen CH, Metsemakers JF, van Weel C, van Schayck O. Self-management in osteoarthritis of hip or knee: a randomized clinical trial in a primary healthcare setting. Journal of Rheumatology 2005;32:543-54 25. Buszewicz M, Rait G, Griffin M, Nazareth I, Patel A, Atkinson A, Barlow J, Haines A. Self management of arthritis in primary care: randomized controlled trial. British Medical Journal 2006; doi:10.1136/bmj.38965.375718.80

26. Wetzels R, van Weel C, Grol R, Wensing M . Family practice nurses supporting selfmanagement in older patients with mild osteoarthritis: A randomized trial. BMC Family Practice 2008;9:7; doi: 10.1186/1471-1-2296-9-7.

27. Hurley MV, Walsh NE, Mitchell HL, Pimm TJ, Patel A, Williamson E, Jones RH, Dieppe PA, Reeves BC (2007a). Clinical effectiveness of a rehabilitation program integrating exercise, selfmanagement and active coping strategies for chronic knee pain: a cluster randomised controlled trial. Arthritis and Rheumatism 2007a;57:1211-1219.

28. Rosemann T, Joos S, Laux G, Gensichen J, Szecsenyi J. Case management of arthritis patients in primary care: a cluster-randomised controlled trial. Arthritis Rheum 2007;57:13901397.

29. Yip YB, Sit JWH, Fung KKY, Wong DYS, Chong YC, Chung LLH, Ng TP. Effects of a selfmanagement arthritis programme with an added exercise component for osteoarthritic knee: randomized controlled trial. J Advanced Nursing 2007;59:20-28.

30. Yip YB, Sit JWH, Wong DYS, Chung LLH. A 1-year follow-up of an experimental study of a self-management arthritis programme with an added exercise component of clients with osteoarthritis of the knee. Psychol Health Med 2008;13:402-414. 
31. Patel A, Buszewicz M, Beecham J, et al Economic evaluation of arthritis self-management in primary care. British Medical Journal 2009;339:b3532 .

32. Hurley MV, Walsh NE, Mitchell HL, Pimm TJ, Williamson E, Jones RH, Reeves BC, Dieppe PA, Patel A. Economic evaluation of a rehabilitation program integrating exderrcise, selfmanagement and active coping strategies for chronic knee pain. Arthritis and Rheumatism 2007b; 57: $1220-1229$

33. Riemsma RP, Taal E, Rasker JJ. Group education for patients with rheumatoid arthritis and their partners. Arthritis Rheum 2003;49:556-566

34. Van Lankveld W, van Helmond T, Naring G, de Rooij DJ, van den Hoogen F. Partner participation in cognitive-behaioural self-management group treatment for patients with rheumatoid arthritis. J Rheumatol 2004;31:1738-1745.

35. Kirwan JR, Helwtt S, Cockshott Z, Barrett J. Clinical and psychological outcomes of patient education in rheumatoid arthritis. Musculoskeletal Care 2005;3:1-16

36. Giraudet-leQuintrec J-S, Mayoux-Benhamou A, Ravaud P, et al. Effect of a collective educational program for patients with rheumatoid arthritis: a prospective 12-month randomized controlled trial. Journal of Rheumatology 2007;34:1684-1691.

37. Hammond A, Bryan J, Hardy A. Effects of a modular behavioral arthritis education programme: A pragmatic parallel-group randomized controlled trial. Rheumatology 2008;47:1712-1718.

38. Soares JJF, Grossi G. A randmoised controlled comparison of educational and behavioural interventions for women with fibromyalgia. Scandinavian J Occupational Therapy 2002;9:35-45. 39. King SJ, Wessel J, Bhambhani Y, Sholter D, Maksymowych W. The effects of exercise and education, individually or combined, in women with fibromyalgia. Journal of Rheumatology 2002;29: 2620-2627.

40. Cedraschi C, Desmeules J, Rapiti E et al. Fibromyalgia: a randomized controlled trial of a treatment programme base don self-management. Annals of the Rheumatic Diseases 2004;63:290-296

41. Ziljstra TR, van der Laar MAFJ, Bernelot Moens HJ et al (2005) Spa treatment for primary 
fibromyalgia syndrome: a combination of thalassotherapy, exercise and patient education improves symptoms and quality of life. Rheumatology 2005;44:539-546

42. Lemstra M, Olszynski WP. The effectiveness of multidisciplinary rehabilitation in the treatment of fibromyalgia: a randomized controlled trial. Clin J Pain. 2005;21:166-74.

43. Hammond A, Freeman K. Community patient education and exercise for people with fibromyalgia: A parallel group randomized controlled trial. Clinical Rehabil 2006;20:835-846. 44. Rooks DS, Gautam S, Romeling M, Cross ML, Stratigakis D, Evans B, Goldenberg DL, Iversen MD, Katz JN. Group exercise, education and combination self-management in women with fibromyalgia: a randomised trial. Archives Internal Med 2007;167:2192-2200.

45. Busch AJ, Barber KA, Overend TJ, Peloso PMJ, Schachter CL. Exercise for treating fibromyalgia syndrome. Cochrane Database of Systematic Reviews 2007;4. No.: CD003786. DOI: 10.1002/14651858.CD003786.pub2.

46. Lorig KR, Mazonson PD, Holman HR. Evidence suggesting that health education for selfmanagement in patients with chronic arthritis has sustained health benefits while reducing health care costs. Arthritis Rheum 1993;36:439-446.

48. Solomon DH, Warsi A, Brown-Stevension T et al. Does self-management education benefit all populations with arthritis? A randomized controlled trial in a primary care physician network. J Rheumatol 2002;29:362-368 
Table 1: Studies of Self-Management in Persons with Arthritis (Osteoarthritis, Rheumatoid Arthritis, Fibromyalgia and other arthritic conditions

\begin{tabular}{|c|c|c|c|c|c|c|c|}
\hline Author (yr) & $\begin{array}{l}\text { Design and Sample }(\mathrm{n}) \text { : } \\
\text { Diagnoses }(\%) ; \\
\text { Mean age }(\mathrm{y}) ; \% \text { women; } \\
\text { arthritis duration }(\mathrm{y})\end{array}$ & $\begin{array}{l}\text { Recruitment } \\
\text { source } \\
\text { \% Drop out }\end{array}$ & $\begin{array}{l}\text { Intervention, Duration, Booster, } \\
\text { Comparison Group }\end{array}$ & $\begin{array}{l}\text { Facilitator; } \\
\text { Training } \\
\text { provided } \\
(\mathrm{Y} / \mathrm{N})\end{array}$ & Theory & $\begin{array}{l}\text { Follow- } \\
\text { up }\end{array}$ & $\begin{array}{l}\text { Significant Outcomes: } \\
\text { Improved }\end{array}$ \\
\hline $\begin{array}{l}\text { Lorig et al } \\
(2004)\end{array}$ & $\begin{array}{l}\text { RCT } n=1090 \\
\text { OA (40\%); RA (60\%); } \\
62 \text { y; } 77 \% \text { women } \\
\text { Duration - not stated }\end{array}$ & $\begin{array}{l}\text { CV } \\
\text { Drop-out: } \\
\text { 12m: } 10 \% \\
24 \mathrm{~m}: 9 \% \\
36 \mathrm{~m}: 15 \%\end{array}$ & $\begin{array}{l}\text { (a) SMART (individually } \\
\text { tailored print materials } \\
\text { based on the ASMP) plus } \\
\text { the Arthritis Helpbook. } \\
\text { Booster: follow-up materials } \\
\text { every } 4 \text { months for } 12 \text { to } 18 \\
\text { months. } \\
\text { (b) usual care }\end{array}$ & $\begin{array}{l}\text { Self- } \\
\text { completed }\end{array}$ & SCT & $\begin{array}{l}12,24 \\
\text { and } 36 \mathrm{~m}\end{array}$ & $\begin{array}{l}\text { CC and ITT analysis } \\
\text { 12m: SMART: } \\
\text { function, role } \\
\text { function, self-efficacy } \\
24 \mathrm{~m} \text { : global severity, } \\
\text { doctor visits } \\
36 \mathrm{~m} \text { : no difference }\end{array}$ \\
\hline $\begin{array}{l}\text { Lorig et al } \\
(2004)^{15}\end{array}$ & $\begin{array}{l}\text { Randomized parallel } \\
\text { group trial n=341 } \\
\text { OA (70\%); RA (30\%); } \\
65 \text { y; } 75 \% \text { women } \\
\text { Duration- not stated }\end{array}$ & $\begin{array}{l}\text { CV } \\
\text { Drop-out: } \\
\text { 12m: } 5 \% \\
24 \mathrm{~m}: 7 \% \\
34 \mathrm{~m}: 21 \%\end{array}$ & $\begin{array}{l}\text { (a) SMART (as above) } \\
\text { (b) } 6 \text { x } 2 \mathrm{~h} / \text { wk ASMP (6 x } \\
\text { 2h/week: action-planning, } \\
\text { problem solving, decision- } \\
\text { making; exercise, cognitive } \\
\text { symptom, pain, fatigue, } \\
\text { sleep management; } \\
\text { nutrition, communication } \\
\text { plus Arthritis Handbook. No } \\
\text { booster. } \\
\text { No control group }\end{array}$ & $\mathrm{PM}(\mathrm{Y})$ & SCT & $\begin{array}{l}12,24 \\
\text { and } 36 \mathrm{~m}\end{array}$ & $\begin{array}{l}\text { ITT analysis } \\
12 \mathrm{~m} \text { : SMART: } \\
\text { function, social role } \\
\text { function, self-efficacy } \\
24 \mathrm{~m} \text { : no differences } \\
36 \mathrm{~m} \text { : ASMP: social } \\
\text { role function, doctor } \\
\text { visits }\end{array}$ \\
\hline $\begin{array}{l}\text { Lorig et al } \\
(2005)^{16}\end{array}$ & $\begin{array}{l}\text { Randomized parallel } \\
\text { group trial n=355 } \\
\text { OA }(75 \%) ; \text { RA (15\%); } \\
\text { Other }(15 \%) \\
65 y ; 85 \% \text { women; } \\
\text { Duration - not stated }\end{array}$ & $\begin{array}{l}\text { CV } \\
\text { Drop-out: } \\
\text { 4m: } 9 \% \\
\text { 12m: } 15 \%\end{array}$ & $\begin{array}{l}\text { (a) ASMP } 6 \times 2 \mathrm{~h} / \mathrm{wk} \text { (see } \\
\text { above) } \\
\text { (b) CDSMP } 6 \times 2 \mathrm{~h} / \text { wk (content } \\
\text { similar to ASMP } \\
\text { (No booster either group) } \\
\text { No control group }\end{array}$ & $\mathrm{PM}(\mathrm{Y})$ & SCT & $\begin{array}{l}4 \text { and } \\
12 \mathrm{~m}\end{array}$ & $\begin{array}{l}\text { ITT analysis: } \\
\text { 12m: Within group: } \\
\text { ASMP pain, fatigue, } \\
\text { self-efficacy, health } \\
\text { distress, activity } \\
\text { limitation, exercise. } \\
\text { CDSMP: global } \\
\text { health, activity } \\
\text { limitation, exercise. } \\
12 \text { m: Between } \\
\text { group: ASMP } \\
\text { fatigue, global health }\end{array}$ \\
\hline Nour et al & RCT $n=125$ housebound & $\mathrm{CHC}$ & (a) Self-management & $\mathrm{HP}(\mathrm{Y})$ & CBT & $1 \mathrm{w}$ and & $\mathrm{CC}$ analysis \\
\hline
\end{tabular}




\begin{tabular}{|c|c|c|c|c|c|c|c|}
\hline $\begin{array}{l}(2006, \\
\text { 2007); } 18,19 \\
\text { Laforest et } \\
\text { al }(2008)\end{array}$ & $\begin{array}{l}113 \text { randomized } \\
\text { OA } 65 \% ; \text { RA } 35 \% \\
78 y ; 90 \% \text { women } \\
\text { Duration- not stated }\end{array}$ & $\begin{array}{l}\text { Drop-out: } \\
8 m \text { 22\% }\end{array}$ & $\begin{array}{l}\text { programme: "I'm Taking } \\
\text { Charge of my Arthritis." } \\
\text { (ITCA: exercise; relaxation; } \\
\text { everyday coping } \\
\text { behaviours; leisure } \\
\text { activities; social networking) } \\
\text { Individually tailored } 6 \text { x } \\
\text { 1h/wk home visits by health } \\
\text { care practitioner; Booster: } \\
42 \% \text { monthly telephone } \\
\text { calls for } 6 m \\
\text { (b) one year wait list control }\end{array}$ & & & $8 m$ & $\begin{array}{l}1 \mathrm{w} \text { : ITCA: function, } \\
\text { helplessness, } \\
\text { behaviours (exercise, } \\
\text { relaxation) } \\
8 \mathrm{~m} \text { : exercise }\end{array}$ \\
\hline $\begin{array}{l}\text { Goeppinger } \\
\text { et al (2007) } \\
21\end{array}$ & $\begin{array}{l}\text { Randomized parallel } \\
\text { group trial n= } 416 \\
\text { (predominantly African } \\
\text { Americans) } \\
\text { Diagnosis: "arthritis" } \\
64 y ; 82 \% \text { women; } \\
\text { Duration - not stated }\end{array}$ & $\begin{array}{l}\text { CV } \\
\text { Drop-out } \\
4 \mathrm{~m}: 23 \% \\
12 \mathrm{~m}: 60 \% \\
\text { (but only } 40 \% \\
\text { contacted) }\end{array}$ & $\begin{array}{l}\text { (a) ASMP } 6 \times 2 h / w k \\
\text { (b) CDSMP } 6 \times 2 h / w k \\
\text { (No booster either group) } \\
\text { No control group }\end{array}$ & $\mathrm{PM}(\mathrm{Y})$ & SCT & $\begin{array}{l}4 \text { and } \\
12 m\end{array}$ & $\begin{array}{l}\text { CC analysis: } \\
\text { 4m: Both groups: } \\
\text { self-efficacy, global } \\
\text { health. } \\
\text { ASMP group: } \\
\text { exercise use } \\
\text { CDSMP: pain. } \\
\text { 12m: ASMP only: } \\
\text { self-efficacy }\end{array}$ \\
\hline $\begin{array}{l}\text { Lorig et al } \\
(2008)^{17}\end{array}$ & $\begin{array}{l}\text { RCT } n=855 \\
\text { OA 64\%; RA 28\%; FM } \\
\text { 52\%; Other } 14 \% \\
\text { 52y; } 60 \% \text { women; } \\
\text { duration - not stated }\end{array}$ & $\begin{array}{l}\text { CV } \\
\text { OV } \\
\text { Drop-out: } \\
\text { 6m 25\% } \\
12 \mathrm{~m} \mathrm{24 \%}\end{array}$ & $\begin{array}{l}\text { (a) Internet -based ASMP log- } \\
\text { on } 1-2 \mathrm{~h}>=3 \mathrm{x} / \text { wk for } 6 \\
\text { wks: self-tests; read } \\
\text { information; post action } \\
\text { plans, participate in } \\
\text { discussion board; tailored } \\
\text { exercise programme; } \\
\text { Arthritis Helpbook. No } \\
\text { booster. } \\
\text { (b) Usual care }\end{array}$ & $\mathrm{PM}(\mathrm{Y})$ & SCT & $\begin{array}{l}6 \text { and } \\
12 m\end{array}$ & $\begin{array}{l}\text { ITT analysis: } \\
\text { 12m: IASMP: pain, } \\
\text { activity limitation, } \\
\text { global health, self- } \\
\text { efficacy, health } \\
\text { distress. } \\
\text { OA only ( } n=292) \text { : as } \\
\text { above + function, } \\
\text { fatigue } \\
\text { RA only ( } n=144) \text { : } \\
\text { pain, activity } \\
\text { limitation, global } \\
\text { health only. } \\
\text { FM only ( } n=86) \text { : no } \\
\text { differences. }\end{array}$ \\
\hline $\begin{array}{l}\text { Goeppinger } \\
\text { et al (2009) }\end{array}$ & $\begin{array}{l}\mathrm{RCT} n=921 \\
\text { three ethnic/racial }\end{array}$ & CV (90\%) & $\begin{array}{l}\text { (a) Mailed ASMP-based Tool } \\
\text { Kit (TK): self-test to }\end{array}$ & $\begin{array}{l}\text { Self- } \\
\text { completed }\end{array}$ & SCT & $\begin{array}{l}4 \text { and } \\
9 \mathrm{~m}\end{array}$ & ITT analysis: \\
\hline
\end{tabular}




\begin{tabular}{|c|c|c|c|c|}
\hline 22 & $\begin{array}{l}\text { categories. } \\
\text { OA 51\%; RA 33\%; } \\
\text { FM 30\%; Other 17\%. } \\
\text { 54y; } 86 \% \text { women; } \\
\text { duration - not stated }\end{array}$ & 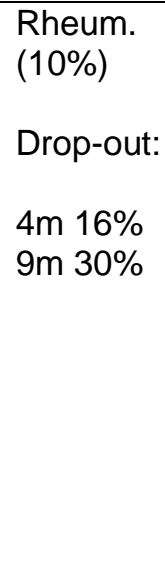 & $\begin{array}{l}\text { evaluate arthritis impact } \\
\text { and tailoring selected } \\
\text { information; information } \\
\text { sheets for e.g. exercise, } \\
\text { dealing with emotions, } \\
\text { fatigue/ pain management, } \\
\text { HP communication; how to } \\
\text { action plan, problem solve, } \\
\text { decide what to try, } \\
\text { individualize exercise; } \\
\text { Arthritis Helpbook and } \\
\text { relaxation/exercise CDs. No } \\
\text { booster. } \\
\text { (b) } 4 \mathrm{~m} \text { wait list control group. }\end{array}$ & $\begin{array}{l}\text { 4m: TK: pain, fatigue, } \\
\text { function, global } \\
\text { health, self-efficacy, } \\
\text { depression, health } \\
\text { distress, exercise, } \\
\text { doctor } \\
\text { communication. } \\
9 m \text { : (No control group } \\
\text { comparison). } \\
\text { Benefits sustained. }\end{array}$ \\
\hline
\end{tabular}


Table 2: Studies of Self-Management in Persons with Osteoarthritis Only

\begin{tabular}{|c|c|c|c|c|c|c|c|}
\hline Author (yr) & $\begin{array}{l}\text { Design and Sample }(\mathrm{n}) \text { : } \\
\text { Mean age }(\mathrm{y}) ; \% \text { women; } \\
\text { arthritis duration }(\mathrm{y})\end{array}$ & $\begin{array}{l}\text { Recruitment } \\
\text { source } \\
\% \text { Drop out }\end{array}$ & $\begin{array}{l}\text { Intervention, Duration, } \\
\text { Comparison Group }\end{array}$ & $\begin{array}{l}\text { Facilitator } \\
\text { Training } \\
\text { provided } \\
(\mathrm{Y} / \mathrm{N})\end{array}$ & Theory & $\begin{array}{l}\text { Follow- } \\
\text { up }\end{array}$ & $\begin{array}{l}\text { Significant Outcomes: } \\
\text { Improved }\end{array}$ \\
\hline $\begin{array}{l}\text { Victor et al } \\
(2005)^{23}\end{array}$ & $\begin{array}{l}\text { Cluster RCT of } 22 \\
\text { practices for } n=193 \\
\text { patients with knee OA } \\
63.5 \text { y ; } 69 \% \text { women } \\
\text { Duration }-55 \% \text { had OA } \\
\text { for more than } 3 \text { years }\end{array}$ & $\begin{array}{l}\text { PC } \\
\text { Drop out: } \\
12 \mathrm{~m} 35 \%\end{array}$ & $\begin{array}{l}\text { (a) Home visit to review goals, } \\
\text { educational booklet and } 4 \\
\text { x1 h group teaching } \\
\text { sessions ( } 6 \text { to } 8 \\
\text { participants) led nurse } \\
\text { educator at GP office } \\
\text { (b) Educational leaflet about } \\
\text { arthritis only }\end{array}$ & $\mathrm{RN}(\mathrm{NS})$ & $\begin{array}{l}\text { Not } \\
\text { stated }\end{array}$ & $\begin{array}{l}1,3,6 \\
\text { and } 12 \mathrm{~m}\end{array}$ & $\begin{array}{l}\text { CC analysis } \\
1 \text { and } 12 \mathrm{~m}: \text { No } \\
\text { differences }\end{array}$ \\
\hline $\begin{array}{l}\text { Heuts et al } \\
(2005)^{24}\end{array}$ & $\begin{array}{l}\text { RCT } n=297 \text { Hip and/or } \\
\text { knee OA aged } 40-60 \\
\text { years. } \\
51.5 y ; 60 \% \text { women } \\
\text { Duration - not stated }\end{array}$ & $\begin{array}{l}\text { PC } \\
\text { Drop out: } \\
3 \mathrm{~m}: 9 \% \\
21 \mathrm{~m}: \mathrm{NS}\end{array}$ & $\begin{array}{l}\text { (a) SMP: } 6 \times 2 h \text { (goal-setting, } \\
\text { exercise (resistance), } \\
\text { relaxation, problem-solving, } \\
\text { communication, emotions, } \\
\text { assistive devices, action plans } \\
\text { and feedback) plus participant } \\
\text { handbook. No booster. } 12 \mathrm{~h} \text {. } \\
\text { (b) usual care }\end{array}$ & PT (Y) & CBT & $\begin{array}{l}3 \mathrm{~m} \\
21 \mathrm{~m}\end{array}$ & $\begin{array}{l}\text { ITT analysis: } \\
\text { 3m: SMP: pain, } \\
\text { function } \\
21 \mathrm{~m}: \text { SMP: pain, } \\
\text { function }\end{array}$ \\
\hline $\begin{array}{l}\text { Buszewicz } \\
\text { et al (2006) } \\
25 \\
\text { Patel et al } \\
(2006)^{31}\end{array}$ & $\begin{array}{l}\text { RCT } n=812 \\
>50 y \text { with hip and/or } \\
\text { knee OA } \\
68 y ; 63 \% \text { women } \\
\text { Duration - not stated }\end{array}$ & $\begin{array}{l}\text { PC } \\
\text { Drop out: } \\
4 \mathrm{~m}: 20 \% \\
\text { 12m: } 24 \%\end{array}$ & $\begin{array}{l}\text { (a) ASMP: } 6 \times 2 \mathrm{~h} \text { plus } \\
\text { information booklet. No } \\
\text { booster. } 12 \mathrm{~h} \text {. } \\
\text { (b) Information booklet }\end{array}$ & $\mathrm{PM}(\mathrm{Y})$ & SCT & $\begin{array}{l}4 \text { and } \\
12 \mathrm{~m}\end{array}$ & $\begin{array}{l}\text { ITT analysis: } \\
\text { 4m: ASMP: self- } \\
\text { efficacy, anxiety, } \\
\text { depression } \\
12 \text { m: ASMP: self- } \\
\text { efficacy, anxiety }\end{array}$ \\
\hline $\begin{array}{l}\text { Hurley et al } \\
(2007 a \text { and } \\
\text { b) } 27,32\end{array}$ & $\begin{array}{l}\text { Cluster RCT } n=418 \\
>50 y ; \text { chronic knee pain } \\
>6 \mathrm{~m} \\
66 \mathrm{y} ; 70 \% \text { women } \\
\text { Median Duration - 6y }\end{array}$ & $\begin{array}{l}\text { PC } \\
\text { Drop-out: } \\
7.5 \mathrm{~m}: 20 \%\end{array}$ & $\begin{array}{l}\text { (a) Exercise and SMP } \\
\text { (ESCAPE): group: } 12 \\
\text { sessions 2x/week for } 6 \\
\text { weeks (goal-setting, action } \\
\text { plans, pain, pacing, } \\
\text { healthy eating, relaxation, } \\
\text { graded class and home } \\
\text { exercise programmes). No } \\
\text { booster. 12h. } \\
\text { (b) ESCAPE: individual (as }\end{array}$ & $\begin{array}{l}\text { PT (not } \\
\text { stated) }\end{array}$ & SCT & $7.5 \mathrm{~m}$ & $\begin{array}{l}\text { ITT analysis: } \\
7.5 \mathrm{~m} \text { : both ESCAPE } \\
\text { groups: pain, } \\
\text { function, anxiety. } \\
\text { Group more cost- } \\
\text { effective than } \\
\text { individual. }\end{array}$ \\
\hline
\end{tabular}




\begin{tabular}{|c|c|c|c|c|c|c|c|c|}
\hline & & & & $\begin{array}{l}\text { above). } \\
\text { (c) Usual care }\end{array}$ & & & & \\
\hline $\begin{array}{l}\text { Yip et al } \\
(2007)^{29}\end{array}$ & $\begin{array}{l}\text { RCT } n=182 \text { Knee OA } \\
\text { 65y; } 75 \% \text { women } \\
\text { Duration: } 8 \text { y }\end{array}$ & $\begin{array}{l}\text { Ortho } \\
\text { Drop out: } \\
\text { 1w: } 18 \% \\
4 \mathrm{~m}: 34 \%\end{array}$ & $\begin{array}{l}\text { (a) } \\
\text { (b) }\end{array}$ & $\begin{array}{l}\text { Modified ASMP: } 6 \times 2 \mathrm{~h} / \mathrm{wk} \\
\text { plus exercise (inc. } \\
\text { increased exercise: } 30 \text { mins } \\
\text { Tai Chi/week, stretching, } \\
\text { home walking + } \\
\text { pedometer). Arthritis } \\
\text { Handbook. No booster. } \\
12 \mathrm{~h} \text {. } \\
\text { usual care only }\end{array}$ & $\mathrm{RN}(\mathrm{Y})$ & SCT & $\begin{array}{l}1 w \text { and } \\
4 m\end{array}$ & $\begin{array}{l}\text { ITT analysis: } \\
\text { 1w: ASMP: pain, } \\
\text { function, } \\
\text { self-efficacy, health } \\
\text { behaviors } \\
\text { 4m: ASMP: pain, } \\
\text { function, self-efficacy, } \\
\text { health behaviors } \\
\text { (hot/cold packs, joint } \\
\text { protection, exercise), }\end{array}$ \\
\hline $\begin{array}{l}\text { Rosemann } \\
\text { et al (2007) } \\
28\end{array}$ & $\begin{array}{l}\text { Cluster RCT } n=75 \\
\text { practices; } 1021 \text { patients } \\
\text { knee or hip OA } \\
66 y ; 66 \% \text { women } \\
\text { Duration: not stated }\end{array}$ & $\begin{array}{l}\text { PC } \\
\text { Drop-out: } \\
6 \mathrm{~m} \mathrm{22 \%}\end{array}$ & $\begin{array}{l}\text { (a) } \\
\text { (b) } \\
\text { (c) }\end{array}$ & $\begin{array}{l}\text { GP delivered SMI: } \\
\text { individual; motivating } \\
\text { patients, evidence based } \\
\text { self-management } \\
\text { information; audio exercise } \\
\text { CD; information leaflet. } \\
\text { Duration not stated. } \\
\text { GP-SMI plus RN monthly } \\
\text { structured telephone case } \\
\text { management over } 6 \mathrm{~m} \text {. } \\
\text { Usual care }\end{array}$ & $\begin{array}{l}\text { GPs (Y); } \\
\operatorname{RN}(Y)\end{array}$ & NS & $9 m$ & $\begin{array}{l}\text { ITT analysis } \\
\text { 9m: GP-SMI: fewer } \\
\text { X-ray referrals and } \\
\text { increased } \\
\text { acetaminophen } \\
\text { prescriptions. } \\
\text { GP-SMI + case } \\
\text { management: pain, } \\
\text { mobility, social } \\
\text { support; fewer X-ray, } \\
\text { orthopedic referrals, } \\
\text { increased } \\
\text { acetaminophen } \\
\text { prescriptions. }\end{array}$ \\
\hline $\begin{array}{l}\text { Yip et al } \\
(2008)^{30}\end{array}$ & $\begin{array}{l}\text { RCT } n=95 \text { Knee OA } \\
63 y ; 85 \% \text { female } \\
\text { Duration: } 7 y\end{array}$ & $\begin{array}{l}\text { PC } \\
\text { Drop Out: } \\
\text { 1w: } 19 \% \\
4 \mathrm{~m}: 22 \% \\
12 \mathrm{~m}: 44 \%\end{array}$ & (a) & $\begin{array}{l}\text { Modified ASMP: } 6 \times 2 \mathrm{~h} / \text { wk } \\
\text { plus exercise (inc. } \\
\text { increased exercise: } 30 \text { mins } \\
\text { Tai Chi/week, stretching, } \\
\text { home walking + } \\
\text { pedometer). Arthritis } \\
\text { Handbook. No booster. } \\
12 \mathrm{~h} \text {. } \\
\text { Usual care only }\end{array}$ & $\mathrm{RN}(\mathrm{Y})$ & SCT & $\begin{array}{l}1 \mathrm{w}, 4 \\
\text { and } 12 \mathrm{~m}\end{array}$ & $\begin{array}{l}\text { ITT Analysis } \\
12 \mathrm{~m}: \text { ASMP: pain } \\
\text { (overall, at night, } \\
\text { when walking), global } \\
\text { health, self-efficacy, } \\
\text { unplanned doctor } \\
\text { visits for arthritis. }\end{array}$ \\
\hline
\end{tabular}




\begin{tabular}{|c|c|c|c|c|c|c|c|c|}
\hline $\begin{array}{l}\text { Wetzels et } \\
\text { al }(2008)^{26}\end{array}$ & $\begin{array}{l}\text { RCT } n=104 ; \text { mild hip or } \\
\text { knee OA } \\
74 y ; 76 \% \text { women } \\
\text { Duration - not stated }\end{array}$ & $\begin{array}{l}\text { PC } \\
\text { Dropout } \\
6 \mathrm{~m}: 14 \%\end{array}$ & (a & $\begin{array}{l}\text { Individual SMP: OA } \\
\text { booklet; self-identification of } \\
\text { problems; } 30 \text { min home } \\
\text { visit x } 1 \text {; agree to change } 1 \\
\text { of } 4 \text { behaviours (exercise, } \\
\text { weight loss, walk aid use, } \\
\text { medication); } 3 \mathrm{~m} \text { telephone } \\
\text { follow-up. Approx. } 1 \mathrm{~h} \\
\text { OA booklet }\end{array}$ & $\mathrm{RN}(\mathrm{N})$ & $\mathrm{NS}$ & $6 n$ & $\begin{array}{l}\text { CC analysis: } \\
6 \mathrm{~m}: \text { no difference }\end{array}$ \\
\hline
\end{tabular}


Table 3: Studies of Self-Management in Persons with Inflammatory Arthritis only

\begin{tabular}{|c|c|c|c|c|c|c|c|}
\hline Author (yr) & $\begin{array}{l}\text { Design and Sample }(\mathrm{n}) \text { : } \\
\text { Mean age }(\mathrm{y}) ; \% \text { women; } \\
\text { arthritis duration }(\mathrm{y})\end{array}$ & $\begin{array}{l}\text { Recruitment } \\
\text { source } \\
\text { \% Drop out }\end{array}$ & $\begin{array}{l}\text { Intervention, Duration, } \\
\text { Comparison Group }\end{array}$ & Facilitator & Theory & $\begin{array}{l}\text { Follow- } \\
\text { up }\end{array}$ & $\begin{array}{l}\text { Significant Outcomes: } \\
\text { Improved }\end{array}$ \\
\hline $\begin{array}{l}\text { Riemsma } \\
\text { et al (2003) } \\
33\end{array}$ & $\begin{array}{l}\text { RCT } n=218 \text { RA } \\
56 y ; 62 \% \text { women } \\
\text { Duration: } 12 \text { y }\end{array}$ & $\begin{array}{l}\text { Rheum } \\
\text { Drop-out: } \\
12 \mathrm{~m} 17 \%\end{array}$ & $\begin{array}{l}\text { (a) self-management } \\
\text { programme (SMP) } 5 \times 2 \mathrm{~h} / \mathrm{wk} \\
\text { (pain management, relaxation, } \\
\text { coping with depression, } \\
\text { communication, exercise } \\
\text { advice) plus } 3 \times 2 \mathrm{~h} \text { booster: } 3,6 \\
\text { and } 9 \text { months + partner. } 16 \mathrm{~h} \\
\text { (b) as above without partner; } \\
\text { (c) self-help guide only }\end{array}$ & 2x RN (Y) & SCT & $\begin{array}{l}6 \text { and } \\
12 \mathrm{~m}\end{array}$ & $\begin{array}{l}\text { ITT analysis: } \\
\text { 6m: Both SMP } \\
\text { groups: exercise. } \\
\text { 12m: SMP without } \\
\text { partner: self-efficacy, } \\
\text { fatigue. }\end{array}$ \\
\hline $\begin{array}{l}\text { Van } \\
\text { Lankveld et } \\
\text { al }(2004)^{34}\end{array}$ & $\begin{array}{l}\text { RCT } n=59 \text { RA } \\
\text { 50y; } 65 \% \text { women } \\
\text { Duration: } 7.2 y\end{array}$ & $\begin{array}{l}\text { Rheum } \\
\text { Drop-out: } \\
6 \mathrm{~m} \mathrm{3 \%}\end{array}$ & $\begin{array}{l}\text { (a) Education and rational } \\
\text { emotive therapy } \\
\text { programme (ED-RET) } 8 \text { x } \\
1.5 \mathrm{~h} / \text { wk for } 4 \text { wks (ED x4: } \\
\text { information; "encourage } \\
\text { practice of active coping } \\
\text { skills" ; } 4 \text { = RET) + partner. } \\
\text { No booster. } 12 \mathrm{~h} \text {. } \\
\text { (b) as above without partner. } \\
\text { No control group }\end{array}$ & $\begin{array}{l}7 \mathrm{MDT} \\
\text { members } \\
\text { (not stated) } \\
\& \mathrm{CP}(\mathrm{Y})\end{array}$ & $\begin{array}{l}\text { CBT \& } \\
\text { RET }\end{array}$ & $\begin{array}{l}2 w \text { and } \\
6 m\end{array}$ & $\begin{array}{l}\text { ITT analysis: } \\
\text { 6m: Both ED-RET } \\
\text { groups: pain, } \\
\text { function, mobility, } \\
\text { dexterity. }\end{array}$ \\
\hline $\begin{array}{l}\text { Kirwan et al } \\
(2005)^{35}\end{array}$ & $\begin{array}{l}\text { RCT (Zelen design) } \\
n=79 \text { RA } \\
\text { 54y; } 61 \% \text { women } \\
\text { Duration } 15 y\end{array}$ & $\begin{array}{l}\text { Rheum } \\
\text { Drop-out: } \\
6 \mathrm{~m} 14 \%\end{array}$ & $\begin{array}{l}\text { (a) education (ED) and CBT } 4 \\
\times 2.5 \mathrm{~h} / \text { week }+1 \times 2.5 \mathrm{~h} \\
\text { booster at } 8 \mathrm{w} \text { (ED: joint } \\
\text { protection, heat and cold; } \\
\text { CBT: managing mood, } \\
\text { pain, relaxation, sleep, } \\
\text { communication, coping). } \\
12.5 \mathrm{~h} \text {. } \\
\text { (b) usual care }\end{array}$ & $\begin{array}{l}5 \text { MDT } \\
\text { members } \\
\text { (not stated) } \\
+ \text { CP \& RN } \\
(Y)\end{array}$ & CBT & $\begin{array}{l}2 \text { and } \\
6 \mathrm{~m}\end{array}$ & $\begin{array}{l}\text { ITT and CC analysis: } \\
\text { CC only at } 2 \mathrm{~m} \text { : } \\
\text { ED-CBT: self-efficacy } \\
6 \mathrm{~m} \text { : no differences. }\end{array}$ \\
\hline $\begin{array}{l}\text { Giraudet-le } \\
\text { Quintrec et } \\
\text { al }(2007)^{36}\end{array}$ & $\begin{array}{l}\text { RCT } n=208 \text { RA } \\
55 y ; 89 \% \text { women }\end{array}$ & $\begin{array}{l}\text { Rheum } \\
\text { Drop-out: }\end{array}$ & $\begin{array}{l}\text { (a) education and self- } \\
\text { management programme (ED- } \\
\text { SMP: ED = } 3 \text { sessions (RA, }\end{array}$ & $\begin{array}{l}10 \text { MDT } \\
\text { members } \\
\text { (not stated) }\end{array}$ & $\begin{array}{l}\text { SCT? } \\
\text { CBT? }\end{array}$ & $\begin{array}{l}6 \text { and } \\
12 \mathrm{~m}\end{array}$ & $\begin{array}{l}\text { ITT analysis: } \\
\text { 12m: ED-SMP coping }\end{array}$ \\
\hline
\end{tabular}




\begin{tabular}{|c|c|c|c|c|c|c|c|}
\hline & Duration 13y & $12 \mathrm{~m} 9 \%$ & $\begin{array}{l}\text { treatment, diet); SMP }=5 \\
\text { sessions ( } 1=\text { pain and stress } \\
\text { management; } 4=\text { exercise, } \\
\text { relaxation, joint protection, foot } \\
\text { care, social advice); } 8 \times 6 \mathrm{~h} / \mathrm{wk} \\
\text { plus } 4 \mathrm{~h} \text { booster at } 6 \mathrm{~m} .52 \mathrm{~h} . \\
\text { (b) information booklets }\end{array}$ & & & & \\
\hline $\begin{array}{l}\text { Hammond } \\
\text { et al (2008) } \\
37\end{array}$ & $\begin{array}{l}\text { RCT } n=167 \\
\text { (RA 50\%; EIA 35\% } \\
\text { PsA 15\%) } \\
\text { 55y; 65\% women; } \\
\text { Duration 7y }\end{array}$ & $\begin{array}{l}\text { Rheum } \\
\text { Drop-out: } \\
12 \mathrm{~m} 17 \%\end{array}$ & $\begin{array}{l}\text { (a) Lifestyle Management for } \\
\text { Arthritis Programme (LMAP): } \\
2 \text { modules: } 4 \times 2.5 \mathrm{~h} / \mathrm{wk} ; 1 \times 2 \mathrm{~h} \\
\text { booster (joint protection, fatigue } \\
\text { management, exercise, foot } \\
\text { care, managing pain and mood; } \\
\text { communication, maintaining } \\
\text { change); self-paced over } 4-6 \\
\text { months. } 22 \mathrm{~h} \text {. } \\
\text { (b) attention control group: } \\
\text { information programme } 5 \mathrm{x} \\
\text { 2h/week. 10h. }\end{array}$ & $\begin{array}{l}2 \text { OTs \& } 1 \\
\text { PT (Y) } \\
\\
6 \text { MDT } \\
\text { members } \\
(\mathrm{N})\end{array}$ & $\begin{array}{l}\text { SCT } \\
\text { CBT } \\
\text { None }\end{array}$ & $\begin{array}{l}6 \text { and } \\
12 m\end{array}$ & $\begin{array}{l}\text { ITT analysis } \\
6 \mathrm{~m} \text { : LMAP: pain, } \\
\text { fatigue, function, } \\
\text { global health, self- } \\
\text { efficacy, mood, } \\
\text { helplessness, } \\
\text { perceived control, } \\
\text { behaviours (exercise, } \\
\text { joint protection), } \\
\text { health care use } \\
\text { 12m: LMAP: pain, } \\
\text { self-efficacy, } \\
\text { perceived control, } \\
\text { behaviours (joint } \\
\text { protection, fatigue } \\
\text { management) }\end{array}$ \\
\hline
\end{tabular}


Table 4: Studies of Self-Management in Persons with Fibromyalgia only

\begin{tabular}{|c|c|c|c|c|c|c|c|}
\hline Author (yr) & $\begin{array}{l}\text { Design and Sample }(\mathrm{n}) \text { : } \\
\text { Mean age }(\mathrm{y}) ; \% \text { women; } \\
\text { arthritis duration (y) }\end{array}$ & $\begin{array}{l}\text { Recruitment } \\
\text { source } \\
\% \text { Drop out }\end{array}$ & $\begin{array}{l}\text { Intervention, Duration, } \\
\text { Comparison Group }\end{array}$ & $\begin{array}{l}\text { Facilitator } \\
\text { Training } \\
(\mathrm{Y} / \mathrm{N})\end{array}$ & Theory & $\begin{array}{l}\text { Follow- } \\
\text { up }\end{array}$ & $\begin{array}{l}\text { Significant Outcomes: } \\
\text { Improved }\end{array}$ \\
\hline $\begin{array}{l}\text { Soares et } \\
\text { al }(2002)^{38}\end{array}$ & $\begin{array}{l}\text { RCT } n=53 \\
45 y: 100 \% \text { women } \\
\text { Duration symptoms } 3.6 y\end{array}$ & $\begin{array}{l}\text { PC } \\
\text { Drop-out: } \\
\text { Not stated }\end{array}$ & $\begin{array}{l}\text { Hospital-based: } \\
\text { (a) Education: individual } \\
\text { sessions }(2 \times 2 \mathrm{~h})+15 \times 2 \mathrm{~h} \\
\text { group sessions over } 10 \mathrm{w} \\
\text { (pain, sleep, stress, } \\
\text { fatigue/ergonomics, } \\
\text { medication, body } \\
\text { awareness). No booster. } \\
34 \mathrm{~h} . \\
\text { (b) } \\
\text { CBT: } 5 \times 1 \mathrm{~h} \text { individual } \\
\text { sessions and } 15 \times 2 \mathrm{~h} \text { group } \\
\text { CBT sessions over } 10 \mathrm{w} \\
\text { (relaxation, biofeedback, } \\
\text { pain and stress } \\
\text { management, negative } \\
\text { thinking, problem-solving); } \\
\text { no booster. } 35 \mathrm{~h} \text {. } \\
\text { (c) wait list control }\end{array}$ & $\begin{array}{l}\text { 10T, 1PT } \\
\text { (not stated) }\end{array}$ & NS & $\begin{array}{l}2.5 \text { and } \\
6 \mathrm{~m}\end{array}$ & $\begin{array}{l}\text { CC analysis: } \\
2.5 \mathrm{~m} \text { : CBT: pain, } \\
\text { function, pain coping, } \\
\text { self-efficacy, sleep } \\
\text { quality } \\
6 \mathrm{~m} \text { : sleep quality }\end{array}$ \\
\hline $\begin{array}{l}\text { King et al } \\
(2002)^{39}\end{array}$ & $\begin{array}{l}\text { RCT } n=152 \\
46 y ; 100 \% \text { women } \\
\text { Duration } 9 y\end{array}$ & $\begin{array}{l}\text { Rheum } \\
\text { Drop-out: } \\
38 \%\end{array}$ & $\begin{array}{l}\text { Community based: } \\
\text { (a) supervised aerobic exercise } \\
\text { (AE) } 12 \text { weeks (up to } 40 \\
\text { mins. } 3 \times / \text { wk } 60-75 \% \text { max. } \\
\text { heart-rate). } 36 \mathrm{~h} \text {. } \\
\text { (b) SMP: } 12 \times 1.5-2 \mathrm{~h} / \text { wk: pain, } \\
\text { fatigue, pacing, exercise } \\
\text { benefits, alternate } \\
\text { therapies, barriers to } \\
\text { change). } 24 \mathrm{~h} \text {. } \\
\text { (c) AE-SMP (combined as } \\
\text { above). } 50 \mathrm{~h} \text {. } \\
\text { (d) Information leaflets }\end{array}$ & $\begin{array}{l}\text { MDT (not } \\
\text { stated) \& } \\
\text { CP } \\
\text { MDT (not } \\
\text { stated) \& } \\
\text { CP (Y) }\end{array}$ & SCT & $\begin{array}{l}3 \text { and } \\
6 m\end{array}$ & $\begin{array}{l}\text { ITT, CC and PP } \\
\text { analyses: } \\
\text { ITT and CC no } \\
\text { differences } \\
3 \text { and } 6 \mathrm{~m} \text { : PP } \\
\text { analysis only: } \\
\text { AE-SMP: self- } \\
\text { efficacy, fitness }\end{array}$ \\
\hline
\end{tabular}




\begin{tabular}{|c|c|c|c|c|c|c|c|}
\hline $\begin{array}{l}\text { Cedraschi } \\
\text { et al (2004) } \\
40\end{array}$ & $\begin{array}{l}\text { RCT } n=129 \\
49 y ; 76 \% \text { women } \\
\text { Duration symptoms } 9 y\end{array}$ & $\begin{array}{l}\text { Rheum } \\
\text { Drop-out } \\
21 \%\end{array}$ & $\begin{array}{l}\text { Hospital based: } \\
\text { (a) SMP and exercise: } 12 \mathrm{x} \\
1.5 \mathrm{~h} \text { sessions for } 6 \text { wks: land } \\
\text { (x2) and warm-water (x8) } \\
\text { exercise, managing daily } \\
\text { activities, relaxation, personal } \\
\text { relationships. No booster. } 18 \mathrm{~h} \text {. } \\
\text { (b) wait list control. }\end{array}$ & $\begin{array}{l}\text { MDT (not } \\
\text { stated) \& } \\
\text { CP }\end{array}$ & NS & $6 m$ & $\begin{array}{l}\text { CC analysis: } \\
6 \mathrm{~m} \text { : SMP: } \\
\text { Fibromyalgia Impact } \\
\text { Questionnaire (FIQ), } \\
\text { pain, fatigue, } \\
\text { psychological status; } \\
\text { satisfaction with } \\
\text { symptom control, } \\
\text { stress reduction, } \\
\text { memory }\end{array}$ \\
\hline $\begin{array}{l}\text { Ziljstra et al } \\
(2005)\end{array}$ & $\begin{array}{l}\text { RCT (Zelen design) } \\
n=134 \\
48 y ; 93 \% \text { women } \\
\text { Duration symptoms 9y }\end{array}$ & $\begin{array}{l}\text { Rheum } \\
\text { CV } \\
\text { Drop-out: } \\
12 \mathrm{~m} \mathrm{5 \%}\end{array}$ & $\begin{array}{l}\text { Tunisia- hotel spa: } \\
\text { (a) } 2.5 \text { weeks spa programme } \\
\text { (SPA): } 7 \times 3 \text { hs } \\
\text { thalassotherapy } 7 \times 1 \mathrm{~h} \\
\text { exercise (stretch, aerobic), } \\
7 \times 1.5 \mathrm{~h} \text { education (role of } \\
\text { emotions, pacing, stress } \\
\text { handling, coping, } \\
\text { medications and alternate } \\
\text { therapies). No booster. } \\
38.5 \mathrm{~h} \text {. } \\
\text { (b) Usual care }\end{array}$ & $\begin{array}{l}\text { HP (not } \\
\text { stated) }\end{array}$ & SCT & $\begin{array}{l}3,6 \text { and } \\
12 \mathrm{~m}\end{array}$ & $\begin{array}{l}\text { CC analysis: } \\
\text { 3m: SPA: } \\
\text { Fibromyalgia Impact } \\
\text { Questionnaire (FIQ: } \\
\text { includes pain and } \\
\text { function), fatigue, } \\
\text { physical health, } \\
\text { tender points, sleep } \\
6 \mathrm{~m} \text { : SPA: fatigue } \\
\text { 12m: SPA: walk time. }\end{array}$ \\
\hline $\begin{array}{l}\text { Lemstra et } \\
\text { al (2005) }\end{array}$ & $\begin{array}{l}\text { RCT } n=79 \\
49 y ; 85 \% \text { women; } \\
\text { Duration } 10 y\end{array}$ & $\begin{array}{l}\text { PC } \\
\text { Drop-out: } \\
3 \mathrm{~m} \mathrm{9 \%} \\
15 \mathrm{~m} \mathrm{56 \%}\end{array}$ & $\begin{array}{l}\text { Community based: } \\
\text { (a) SMP and exercise (SMP- } \\
\text { EX). Exercise: } 18 \times 3 \\
\text { 1h/week group exercise; } \\
\text { SMP (6 weeks): FM } \\
\text { information (3h), pain and } \\
\text { stress management ( } 2 \times 3 \mathrm{~h}) \text {; } \\
\text { nutrition( } 3 \mathrm{~h}) ; 2 \times 20 \text { mins } \\
\text { individual massage. } 28.7 \mathrm{~h} \text {. } \\
\text { (b) Usual care }\end{array}$ & $\begin{array}{l}\text { MDT (not } \\
\text { stated) \& } \\
\text { CP } \\
\text { (cognitive } \\
\text { sessions) }\end{array}$ & NS & $\begin{array}{l}6 \mathrm{w} \text { and } \\
15 \mathrm{~m} \\
\text { (uncontr } \\
\text { olled) }\end{array}$ & $\begin{array}{l}\text { ITT analysis: } \\
6 \text { w: pain, function, } \\
\text { global health, mood } \\
\text { 15m (uncontrolled): } \\
\text { pain, function, mood }\end{array}$ \\
\hline $\begin{array}{l}\text { Hammond } \\
\text { et al (2006) } \\
43\end{array}$ & $\begin{array}{l}\text { RCT } n=18390 \% \\
\text { female, } \\
48.5 \text { y; } 90 \% \text { women } \\
\text { Duration: } 2.7 y \\
\text { (symptoms } 6.5 y \text { ) }\end{array}$ & $\begin{array}{l}\text { Rheum } \\
\text { Drop-out: } \\
\text { 8m } 24 \%\end{array}$ & $\begin{array}{l}\text { Community based: } \\
\text { (a) SMP (pain, fatigue and } \\
\text { stress management, pacing, } \\
\text { sleep, relaxation, exercise (Tai } \\
\text { Chi, home walking programme, } \\
\text { postural training, strengthening) }\end{array}$ & $\begin{array}{l}\text { 1OT, } 1 \mathrm{PT} \\
(\mathrm{Y})\end{array}$ & $\begin{array}{l}\text { SCT; } \\
\text { CBT }\end{array}$ & $\begin{array}{l}4 \text { and } \\
8 m\end{array}$ & $\begin{array}{l}\text { ITT analysis: } \\
\text { 4m: SMP: } \\
\text { Fibromyalgia Impact } \\
\text { Questionnaire (FIQ), } \\
\text { self-efficacy; } \\
\text { perceived control; }\end{array}$ \\
\hline
\end{tabular}




\begin{tabular}{|c|c|c|c|c|c|c|c|}
\hline & & & $\begin{array}{l}10 \times 2 \mathrm{hr} / \text { wk (over } 12 \text { weeks). No } \\
\text { booster. } 20 \mathrm{~h} \\
\text { (b) attention control group: } \\
\text { relaxation programme } 10 \times 1 \\
\text { hr/wk for } 10 \text { weeks. } 10 \mathrm{~h} .\end{array}$ & & & & $\begin{array}{l}\text { health care use } \\
8 \mathrm{~m} \text { : exercise; self- } \\
\text { reported "improved" } \\
\text { status }\end{array}$ \\
\hline $\begin{array}{l}\text { Rooks et al } \\
(2007) 44\end{array}$ & $\begin{array}{l}\text { Randomized parallel } \\
\text { group study } n=207 \\
\text { 50y; } 100 \% \text { women; } \\
\text { Duration } 6 y\end{array}$ & $\begin{array}{l}\text { Rheum } \\
\text { Drop-out: } \\
35 \%\end{array}$ & $\begin{array}{l}\text { Community and hospital based: } \\
\text { (a) aerobic exercise }(\mathrm{AE} \text { : } \\
\text { walking) } 16 \times 2 \times 1 \mathrm{~h} / \mathrm{wk}+\text { home } \\
\text { programme } 1 \times / \text { wk; } 32 \mathrm{~h} \text {. } \\
\text { (b) strength and aerobic } \\
\text { exercise (STAE) } 16 \times 2 \times 1 \mathrm{~h} / \mathrm{wk} \text {; } \\
32 \mathrm{~h} \text {. } \\
\text { (c) Fibromyalgia Self-Help } \\
\text { Course (FHSC) } 7 \times 2 \mathrm{~h} / \text { fortnight } \\
\text { (pain, relaxation, exercise, } \\
\text { communication, fatigue, } \\
\text { depression (FM specific version } \\
\text { of ASMP); no booster. } 14 \mathrm{~h} \text {. } \\
\text { (d) combined STAE and } \\
\text { FHSC; no booster. } 46 \mathrm{~h} \text {. } \\
\text { No control group. }\end{array}$ & $\begin{array}{l}\mathrm{PM} / \mathrm{HP} ? \\
(\mathrm{Y})\end{array}$ & SCT & $6 \mathrm{~m}$ & $\begin{array}{l}\text { CC analysis: } \\
\text { 6m: STAE-FHSC: } \\
\text { Fibromyalgia Impact } \\
\text { Questionnaire (FIQ), } \\
\text { pain, fatigue, } \\
\text { function, } \\
\text { AE: fatigue, mood; } \\
\text { STAE: FIQ; pain, } \\
\text { fatigue, mood } \\
\text { All groups: self- } \\
\text { efficacy }\end{array}$ \\
\hline
\end{tabular}




\section{Key:}

Diagnosis: $\mathrm{OA}=$ osteoarthritis; RA = rheumatoid arthritis; EIA = early inflammatory arthritis; PsA = psoriatic arthritis; $F M=$ fibromyalgia

Recruitment: $\mathrm{CV}=$ community volunteers; OV = online volunteers; ORTHO= Orthopedic clinic; $\mathrm{PC}=$ Primary Care; Rheum = Rheumatology outpatient departments; $\mathrm{CHC}=$ Community Health Centers.

Intervention: SMP = self management programme; ASMP = the Arthritis Self-Management Programme; SMART = Mail delivered Arthritis SelfManagement Programme; CDSMP: Chronic Disease Self Management Programme

Programme facilitator: $\mathrm{PM}=$ trained peer/ lay moderator; $\mathrm{HP}=$ Health Professionals; $\mathrm{RN}=$ registered nurse; MDT: multidisciplinary team (nurse, physiotherapist (PT), occupational therapist (OT) (+/- rheumatologist, pharmacist); $\mathrm{CP}=$ clinical psychologist

Training: NS = not stated.

Theory: SCT = Social Cognitive Theory; $\mathrm{CBT}=$ cognitive-behavioural theory; NS = not stated

Analysis: ITT = all cases included, imputation of missing values; $\mathrm{CC}=$ case completers only 
Table 5: Outcome Measures Assessed In Clinical Trials of Self Management Interventions in Arthritis

\begin{tabular}{|c|c|c|c|c|c|c|c|c|c|c|c|c|}
\hline Paper & $\begin{array}{l}\text { Disease } \\
\text { status }\end{array}$ & Pain & Fatigue & $\begin{array}{l}\text { Function } \\
\text { /Disability }\end{array}$ & $\begin{array}{l}\text { Global } \\
\text { health }\end{array}$ & $\begin{array}{l}\text { Self- } \\
\text { efficacy }\end{array}$ & Mood & $\begin{array}{l}\text { Perceived } \\
\text { control }\end{array}$ & Coping & $\begin{array}{l}\text { Social } \\
\text { support/ } \\
\text { role }\end{array}$ & $\begin{array}{l}\text { Health } \\
\text { behaviors }\end{array}$ & $\begin{array}{l}\text { Health } \\
\text { care } \\
\text { use/costs }\end{array}$ \\
\hline \multicolumn{13}{|l|}{$\begin{array}{l}\text { Arthritis: } \\
\text { combined }\end{array}$} \\
\hline $\begin{array}{l}\text { Lorig et al } \\
2004\end{array}$ & $\checkmark^{*}$ & $\checkmark$ & & $\checkmark$ & & $\checkmark$ & $\checkmark$ & & & $\checkmark$ & & $\checkmark$ \\
\hline $\begin{array}{l}\text { Lorig et al } \\
2005\end{array}$ & & $\checkmark$ & $\checkmark$ & $\checkmark$ & $\checkmark$ & $\checkmark$ & $\checkmark$ & & & $\checkmark$ & $\checkmark$ & $\checkmark$ \\
\hline $\begin{array}{l}\text { Goeppinger et } \\
\text { al } 2007\end{array}$ & & $\checkmark$ & $\checkmark$ & $\checkmark$ & $\checkmark$ & $\checkmark$ & $\checkmark$ & & & & $\checkmark$ & $\checkmark$ \\
\hline $\begin{array}{l}\text { Laforest et al } \\
(2008 ; \text { Nour et } \\
\text { al }(2006,2007)\end{array}$ & & $\checkmark$ & $\checkmark$ & $\checkmark$ & & $\checkmark$ & $\checkmark$ & & $\checkmark$ & $\checkmark$ & $\checkmark$ & \\
\hline $\begin{array}{l}\text { Lorig et al } \\
2008\end{array}$ & & $\checkmark$ & $\checkmark$ & $\checkmark$ & $\checkmark$ & $\checkmark$ & $\checkmark$ & & & $\checkmark$ & $\checkmark$ & $\checkmark$ \\
\hline $\begin{array}{l}\text { Goeppinger et } \\
\text { al } 2009\end{array}$ & & $\checkmark$ & $\checkmark$ & $\checkmark$ & $\checkmark$ & $\checkmark$ & $\checkmark$ & & & & $\checkmark$ & $\checkmark$ \\
\hline \multicolumn{13}{|l|}{ Osteoarthritis: } \\
\hline $\begin{array}{l}\text { Victor et al } \\
2005\end{array}$ & & $\checkmark$ & & $\checkmark$ & $\checkmark$ & & $\checkmark$ & $\checkmark$ & $\checkmark$ & & $\checkmark$ & \\
\hline $\begin{array}{l}\text { Heuts et al } \\
2005\end{array}$ & & $\checkmark$ & & $\checkmark$ & $\checkmark$ & $\checkmark$ & & & & & & \\
\hline $\begin{array}{l}\text { Buszewicz et } \\
\text { al 2006; Patel } \\
\text { et al } 2006\end{array}$ & & $\checkmark$ & & $\checkmark$ & & $\checkmark$ & $\checkmark$ & & & & & $\checkmark$ \\
\hline $\begin{array}{l}\text { Hurley et al } \\
2007 a \text { and b }\end{array}$ & & $\checkmark$ & & $\checkmark$ & $\checkmark$ & & $\checkmark$ & & & & $\checkmark$ & $\checkmark$ \\
\hline $\begin{array}{l}\text { Rosemann et } \\
\text { al (2007) }\end{array}$ & & $\checkmark$ & & $\checkmark$ & & & $\checkmark$ & & & $\checkmark$ & & $\checkmark$ \\
\hline Yip et al 2007 & & $\checkmark$ & & $\checkmark$ & & $\checkmark$ & & & & & $\checkmark$ & \\
\hline Yip et al 2008 & & $\checkmark$ & $\checkmark$ & $\checkmark$ & $\checkmark$ & $\checkmark$ & & & & & & $\checkmark$ \\
\hline $\begin{array}{l}\text { Wetzels et al } \\
2008\end{array}$ & & $\checkmark$ & & $\checkmark$ & & $\checkmark$ & & & & $\checkmark$ & $\checkmark$ & $\checkmark$ \\
\hline Inflammatory & & & & & & & & & & & & \\
\hline
\end{tabular}




\begin{tabular}{|c|c|c|c|c|c|c|c|c|c|c|c|c|}
\hline Arthritis: & & & & & & & & & & & & \\
\hline $\begin{array}{l}\text { Riemsma et al } \\
2003\end{array}$ & $\checkmark$ & $\checkmark$ & $\checkmark$ & $\checkmark$ & & $\checkmark$ & $\checkmark$ & & $\checkmark$ & $\checkmark$ & $\checkmark$ & \\
\hline $\begin{array}{l}\text { Van Lankveld } \\
\text { et al } 2004\end{array}$ & $\checkmark$ & $\checkmark$ & & $\checkmark$ & & & $\checkmark$ & & $\checkmark$ & & & \\
\hline $\begin{array}{l}\text { Kirwan et al } \\
2005\end{array}$ & $\checkmark$ & $\checkmark$ & & $\checkmark$ & & $\checkmark$ & $\checkmark$ & $\checkmark$ & $\checkmark$ & & & \\
\hline $\begin{array}{l}\text { Girardet- } \\
\text { leQuintrec et } \\
\text { al } 2007\end{array}$ & $\checkmark$ & $\checkmark$ & $\checkmark$ & $\checkmark$ & & & $\checkmark$ & $\checkmark$ & & & $\checkmark$ & \\
\hline $\begin{array}{l}\text { Hammond et } \\
\text { al } 2008\end{array}$ & $\begin{array}{l}\text { EMS } \\
\text { only }\end{array}$ & $\checkmark$ & $\checkmark$ & $\checkmark$ & $\checkmark$ & $\checkmark$ & $\checkmark$ & $\checkmark$ & & & $\checkmark$ & $\checkmark$ \\
\hline $\begin{array}{l}\text { Fibromyalgia } \\
\text { only }\end{array}$ & $\begin{array}{l}\text { (Tender } \\
\text { points) }\end{array}$ & & & & & & & & & & & \\
\hline $\begin{array}{l}\text { Soares et al } \\
2002\end{array}$ & & $\checkmark$ & $\checkmark$ & $\checkmark$ & $\checkmark$ & $\checkmark$ & $\checkmark$ & & $\checkmark$ & $\checkmark$ & & \\
\hline $\begin{array}{l}\text { King et al } \\
2002\end{array}$ & $\checkmark$ & $\checkmark$ & $\checkmark$ & $\checkmark$ & $\checkmark$ & $\checkmark$ & $\checkmark$ & & & & & \\
\hline $\begin{array}{l}\text { Cedraschi et } \\
\text { al } 2004\end{array}$ & & $\checkmark$ & $\checkmark$ & $\checkmark$ & $\checkmark$ & & $\checkmark$ & & & $\checkmark$ & $\checkmark$ & \\
\hline $\begin{array}{l}\text { Ziljstra et al } \\
2005\end{array}$ & $\checkmark$ & $\checkmark$ & $\checkmark$ & $\checkmark$ & $\checkmark$ & & $\checkmark$ & & & & & \\
\hline $\begin{array}{l}\text { Lemstra et al } \\
2005\end{array}$ & & $\checkmark$ & & $\checkmark$ & $\checkmark$ & & $\checkmark$ & & & & & \\
\hline $\begin{array}{l}\text { Hammond et } \\
\text { al } 2006\end{array}$ & & $\checkmark$ & $\checkmark$ & $\checkmark$ & $\checkmark$ & $\checkmark$ & $\checkmark$ & $\checkmark$ & & & $\checkmark$ & $\checkmark$ \\
\hline $\begin{array}{l}\text { Rooks et al } \\
2007\end{array}$ & & $\checkmark$ & $\checkmark$ & $\checkmark$ & $\checkmark$ & $\checkmark$ & $\checkmark$ & & & $\checkmark$ & & \\
\hline $\begin{array}{l}\text { Lorig et al } \\
2008\end{array}$ & & $\checkmark$ & $\checkmark$ & $\checkmark$ & $\checkmark$ & & $\checkmark$ & & & $\checkmark$ & $\checkmark$ & $\checkmark$ \\
\hline
\end{tabular}

${ }^{*}$ global severity of disease 


\section{TABLE 6: Patient Perspectives on Self-Management Programs and Future Directions}

- Researchers demonstrating positive outcomes from SMls with sufficient sample sizes, should undertake secondary analyses to investigate further whether any patient attributes are associated with better outcomes.

- Examine longer-term (12 months and longer) benefits of SMIs

- Standardize implementation using protocols and participant handbooks. Ensure programs are SCT/CBT based, use trained peer leaders or health professionals, are of sufficient duration and incorporate exercise

- Patient dairies, creative writing or interviews are recommended to explore participants' overall well-being, processes of change and ascertain patient relevant outcomes

- Researchers should include patient-relevant outcomes. If using questionnaires, more frequent measures of outcomes may be useful in tracking the full impact of SMls than longer intervals (baseline, 3 months and one year) 